OPEN ACCESS

Edited by:

Manuel Espinosa,

Centro de Investigaciones Biológicas

(CSIC), Spain

Reviewed by:

Guenther Muth,

Universität Tübingen, Germany

Fabián Lorenzo,

Universidad de La Laguna, Spain

Gloria Del Solar,

Consejo Superior de Investigaciones

Científicas (CSIC), Spain

*Correspondence:

Itziar Alkorta

itzi.alkorta@ehu.eus

Specialty section:

This article was submitted to

Evolutionary and Genomic

Microbiology

a section of the journal

Frontiers in Microbiology

Received: 21 June 2017 Accepted: 02 October 2017 Published: 16 October 2017

Citation:

Águila-Arcos S, Álvarez-Rodríguez I,

Garaiyurrebaso O, Garbisu C, Grohmann E and Alkorta I (2017)

Biofilm-Forming Clinical

Staphylococcus Isolates Harbor Horizontal Transfer and Antibiotic

Resistance Genes.

Front. Microbiol. 8:2018.

doi: 10.3389/fmicb.2017.02018
Biofilm-Forming Clinical

\section{Staphylococcus Isolates Harbor Horizontal Transfer and Antibiotic Resistance Genes}

\author{
Sandra Águila-Arcos ${ }^{1}$, Itxaso Álvarez-Rodríguez ${ }^{1}$, Olatz Garaiyurrebaso ${ }^{1}$, \\ Carlos Garbisu ${ }^{2}$, Elisabeth Grohmann ${ }^{3}$ and Itziar Alkorta ${ }^{1 *}$ \\ ${ }^{1}$ Instituto Biofisika (UPV/EHU, CSIC), Department of Biochemistry and Molecular Biology, University of the Basque Country, \\ Bilbao, Spain, ${ }^{2}$ Department of Conservation of Natural Resources, Soil Microbial Ecology Group, NEIKER-Tecnalia, Derio, \\ Spain, ${ }^{3}$ Life Sciences and Technology, Beuth University of Applied Sciences, Berlin, Germany
}

Infections caused by staphylococci represent a medical concern, especially when related to biofilms located in implanted medical devices, such as prostheses and catheters. Unfortunately, their frequent resistance to high doses of antibiotics makes the treatment of these infections a difficult task. Moreover, biofilms represent a hot spot for horizontal gene transfer (HGT) by bacterial conjugation. In this work, 25 biofilm-forming clinical staphylococcal isolates were studied. We found that Staphylococcus epidermidis isolates showed a higher biofilm-forming capacity than Staphylococcus aureus isolates. Additionally, horizontal transfer and relaxase genes of two common staphylococcal plasmids, pSK41 and pT181, were detected in all isolates. In terms of antibiotic resistance genes, aac6-aph2a, ermC, and tetK genes, which confer resistance to gentamicin, erythromycin, and tetracycline, respectively, were the most prevalent. The horizontal transfer and antibiotic resistance genes harbored on these staphylococcal clinical strains isolated from biofilms located in implanted medical devices points to the potential risk of the development and dissemination of multiresistant bacteria.

Keywords: Staphylococci, biofilm, relaxases, antibiotic resistance, nosocomial infections

\section{INTRODUCTION}

Staphylococci, mainly Staphylococcus aureus and Staphylococcus epidermidis, are well-known causative agents of a large number of human infectious diseases, including skin, soft tissue, respiratory tract, bone, joint and endovascular infections, as well as infections related to implanted medical devices (Otto, 2012; Le et al., 2014). Their pathogenicity is due not only to the virulence factors that they express, but also to the ability of these bacteria to form biofilms (i.e., deeply seated microbial communities attached to inert or living surfaces; Costerton et al., 1999; Otto, 2008). The treatment of biofilm-associated infections is considered a challenging task owing to their inherent resistance to (i) antimicrobial agents and (ii) the host immune system (Hoiby et al., 2010). Moreover, nowadays, the incidence of antibiotic resistant pathogenic bacteria in clinical settings is 
dramatically increasing, making treatment of bacterial infections one of our most serious health threats (Guridi et al., 2015). This problem arises from the resistance phenotype of bacteria that harbor resistance genes in their chromosomal and/or plasmid DNA.

Bacteria can acquire resistance genes by horizontal gene transfer (HGT). Actually, conjugative plasmid-mediated HGT is considered the most important process in the emergence of new resistant pathogens (Schiwon et al., 2013). It is well-documented that bacterial conjugation can occur within biofilms since they provide an ideal situation for the exchange of genetic material of various origins (Christensen et al., 1998; Hausner and Wuertz, 1999). On the other hand, bacterial conjugation can induce biofilm formation since the cell-to-cell contact established for gene exchange favors the close proximity of bacteria required for biofilm formation (Ghigo, 2001; Molin and Tolker-Nielsen, 2003; Reisner et al., 2006; Yang et al., 2008; D’Alvise et al., 2010). This link between biofilms and bacterial conjugation increases both the risk of biofilm-related infections and the conjugative spread of virulence factors.

In this work, we studied 25 staphylococcal biofilm-forming clinical isolates belonging to the following species: $S$. aureus, S. epidermidis, S. hominis, and S. capitis. These species are commonly found on human skin and can cause biofilm-forming healthcare-associated infections. Both horizontal transfer and antibiotic resistance genes were detected in these staphylococcal clinical isolates. This work adds valuable information on the risk of development and dissemination of antibiotic resistance in Staphylococcus biofilm-forming clinical isolates.

\section{MATERIALS AND METHODS}

\section{Bacterial Strains}

A total of 25 staphylococcal biofilm-forming clinical isolates were kindly provided by Hospital Universitario Donostia, Spain. In addition, they provided data on their antibiotic resistance phenotype, determined by diffusion discs on agar. The origin and antibiotic resistance phenotype of each isolate are shown in Table 1.

\section{Growth Conditions}

Swabs from the clinical isolates were plated on tryptic soy agar (TSA) and incubated at $37^{\circ} \mathrm{C}$. Subsequently, a single colony of each isolate was grown in $10 \mathrm{ml}$ of tryptic soy broth (TSB) supplemented with at least two antibiotics to which the strain was phenotypically resistant (see Table 1 ), at $37^{\circ} \mathrm{C}$ overnight. The culture was centrifuged at $8,000 \times \mathrm{g}$ for $10 \mathrm{~min}$. Then, the pellet was resuspended in $2 \mathrm{ml}$ of TSB medium containing $40 \%(\mathrm{v} / \mathrm{v})$ glycerol and stored at $-80^{\circ} \mathrm{C}$.

For this study, strains were grown in TSB medium at $37^{\circ} \mathrm{C}$ and $200 \mathrm{rpm}$. TSB medium and TSA plates were supplemented, when required, with amoxicillin $(8 \mu \mathrm{g} / \mathrm{ml})$, cloxacillin $[2 \mu \mathrm{g} / \mathrm{ml}$ for $S$. aureus and $0.5 \mu \mathrm{g} / \mathrm{ml}$ for coagulase negative staphylococci (CoNS)], erythromycin $(4 \mu \mathrm{g} / \mathrm{ml})$, mupirocin $(520 \mu \mathrm{g} / \mathrm{ml})$, tetracycline $(8 \mu \mathrm{g} / \mathrm{ml})$, gentamicin $(20 \mu \mathrm{g} / \mathrm{ml})$, rifampicin $(2 \mu \mathrm{g} / \mathrm{ml})$, or levofloxacin $(2 \mu \mathrm{g} / \mathrm{ml})$.

\section{DNA Extraction}

Plasmid DNA was extracted from the 25 clinical isolates with the ATP $^{\mathrm{TM}}$ Plasmid Midi kit (ATP biotech Inc., Taiwan), according to the manufacturer's instructions.

\section{Detection of Small Plasmids by Agarose Gel Electrophoresis}

To detect small plasmids (molecular size $<20 \mathrm{~kb}$ ), $1 \mu \mathrm{g}$ of total extracted plasmid DNA was linearized by incubation with $30 \mathrm{U}$ of Aspergillus oryzae nuclease S1 (Sigma, Spain) at $37^{\circ} \mathrm{C}$ for 45 min. Nuclease S1 cuts one strand of the DNA at the nick site and its activity results in linearized plasmids (Germond et al., 1974). Different enzyme concentrations were studied to optimize nuclease S1 digestion (data not shown). Linearized plasmids were visualized on $1 \%(\mathrm{w} / \mathrm{v})$ agarose gels in $1 \times$ TAE buffer.

\section{Detection of Large Plasmids by Pulsed Field Gel Electrophoresis}

Detection of large plasmids (molecular size $>20 \mathrm{~kb}$ ) was carried out by Pulsed Field Gel Electrophoresis (PFGE) as described by Barton et al. (1995) with modifications. Bacteria were grown in $2 \mathrm{ml}$ of TSB medium overnight at $37^{\circ} \mathrm{C}$ and $200 \mathrm{rpm}$. Cultures were diluted in PIV buffer [10 mM Tris- $\mathrm{HCl}(\mathrm{pH} 8), 1 \mathrm{M} \mathrm{NaCl}]$ until $\mathrm{OD}_{600}=1$. Then, $600 \mu$ l of diluted culture were centrifuged at $11,000 \times \mathrm{g}$ for $2 \mathrm{~min}$. Subsequently, the pellet was washed with $500 \mu \mathrm{l}$ of PIV buffer and centrifuged again. The pellet was resuspended in $300 \mu \mathrm{l}$ of PIV buffer and incubated at $42^{\circ} \mathrm{C}$ for $10 \mathrm{~min}$. Next, $150 \mu \mathrm{l}$ of the sample were mixed with 150 $\mu \mathrm{l}$ of $2 \%(\mathrm{w} / \mathrm{v})$ low-melting agarose (BioRad) which had been preincubated at $42^{\circ} \mathrm{C}$. The mixture was transferred into the plugs, incubated at room temperature for $10 \mathrm{~min}$ and, subsequently, for $15 \mathrm{~min}$ at $4^{\circ} \mathrm{C}$. Once solidified, gel plugs were incubated at $37^{\circ} \mathrm{C}$ for $5-6 \mathrm{~h}$ with shaking $(600 \mathrm{rpm})$ in $1 \mathrm{ml}$ of lysis buffer EC [6 mM Tris-HCl (pH 8), $1 \mathrm{M} \mathrm{NaCl}, 100$ mM EDTA (pH 8), $0.2 \%(\mathrm{w} / \mathrm{v})$ sodium deoxycholate, $0.5 \%(\mathrm{w} / \mathrm{v}) \mathrm{n}$-lauroylsarcosine, $100 \mu \mathrm{g} / \mathrm{ml}$ lysozyme, $50 \mu \mathrm{g} / \mathrm{ml}$ lysostaphin]. After cell lysis, gel plugs were transferred to new tubes containing $1 \mathrm{ml}$ of EPS solution [1\% (w/v) n-lauroylsarcosine, 0.5 M EDTA ( $\mathrm{pH} 8)$, $100 \mu \mathrm{g} / \mathrm{ml}$ proteinase $\mathrm{K}]$ and then incubated at $56^{\circ} \mathrm{C}$ for $16-20 \mathrm{~h}$. Next, five washes with $1 \mathrm{ml}$ of TE buffer [ $10 \mathrm{mM}$ Tris- $\mathrm{HCl}$ (pH 8), $1 \mathrm{mM}$ EDTA ( $\mathrm{pH} 8)]$ at $50^{\circ} \mathrm{C}$ for $30 \mathrm{~min}$ each were carried out. For nuclease S1 digestion, each gel plug was cut into two slices. Each slice was incubated twice in $100 \mu \mathrm{l}$ of digestion solution [50 mM NaCl, $30 \mathrm{mM}$ sodium acetate ( $\mathrm{pH} 4.5), 5 \mathrm{mM} \mathrm{ZnSO}_{4}$ ] at room temperature for $15 \mathrm{~min}$. Then, slices were incubated at $37^{\circ} \mathrm{C}$ for $45 \mathrm{~min}$ with $1 \mathrm{U}$ of $A$. oryzae nuclease S1 (Sigma) in $100 \mu \mathrm{l}$ of digestion solution. The reaction was stopped by transferring the slices to $1 \mathrm{ml}$ of TE buffer for $1 \mathrm{~h}$. Digested slices were applied to wells in $1 \%(\mathrm{w} / \mathrm{v})$ Pulsed Field Certified Agarose (BioRad) prepared in $0.5 \times$ TBE buffer [ $45 \mathrm{mM}$ Tris ( $\mathrm{pH} 8$ ), $45 \mathrm{mM}$ boric acid, $1 \mathrm{mM}$ EDTA] and run in CHEF$\mathrm{DR}^{\circledR}$ III System (BioRad) at $6 \mathrm{~V} / \mathrm{cm}$, a field angle of $120^{\circ}$, and switch times of 5 to $35 \mathrm{~s}$ for $22 \mathrm{~h}$. Lambda Ladder PFGE (New England Biolabs, Ispwich, U.S) was used as molecular size marker and pSK41 plasmid $(46.4 \mathrm{~kb})$ was used as positive control. Gels were stained with GelRed Nucleic Acid Stain (Biogen Científica, 
TABLE 1 | Origin and antibiotic resistance phenotype of the Staphylococcal biofilm-forming clinical isolates used in this work.

\begin{tabular}{|c|c|c|c|}
\hline No. & Isolate & Origin & Antibiotic resistance ${ }^{a, b}$ \\
\hline 1 & S. aureus 312042 & Prosthesis & AMX, AMC, CFZ, CLI, CLOX, ERY, LVX \\
\hline 2 & S. aureus 410099 & Prosthesis & AMX, AMC, CFZ, CLOX, GEN, LVX, MUP \\
\hline 4 & S. aureus 339031 & Catheter & AMX, AMC, CFZ, CLI, CLOX, ERY, LVZ \\
\hline 5 & S. aureus 215642 & Prosthesis & AMX \\
\hline 8 & S. capitis 316479 & Prosthesis & AMX, AMC, CFZ, CLOX, GEN, LVX, MUP \\
\hline 9 & S. epidermidis 319622 & Prosthesis & AMX, ERY, TET \\
\hline 10 & S. epidermidis 219691 & Prosthesis & AMX, ERY, LVX, MUP, RIF \\
\hline 11 & S. aureus 214967 & Ulcer & AMX, MUP \\
\hline 12 & S. epidermidis 239879 & Catheter & AMX, AMC, CFZ, CLI, CLOX, ERY, GEN, MUP, TET \\
\hline 17 & S. aureus 339056-2 & Catheter & AMX, AMC, CFZ, CLOX, ERY, LVX \\
\hline 18 & S. aureus 339300 & Catheter & AMX, AMC, CFZ, CLOX, LVX \\
\hline 19 & S. aureus 338503 & Catheter & AMX \\
\hline 20 & S. epidermidis 214627-A & Articular fluid from patient with prosthesis & AMX, AMC, CFZ, CLI, CLOX, CTX, ERY, GEN, LVX, MUP, RIF \\
\hline 21 & S. epidermidis 310301-1 & Articular fluid from patient with prosthesis & AMX, AMC, CFZ, CLI, CLOX, CTX, ERY, GEN, LVX, MUP, RIF \\
\hline 22 & S. epidermidis $338400-1$ & Catheter & AMX, AMC, CFZ, CLOX, MUP \\
\hline 23 & S. epidermidis 338515-1 & Catheter & AMX, AMC, CFZ, CLI, CLOX, CTX, ERY, GEN, MUP, RIF \\
\hline 24 & S. epidermidis 338684 & Catheter & AMX, AMC, CFZ, CLI, CLOX, CTX, GEN, LVX, MUP, RIF \\
\hline 25 & S. epidermidis 216663 & Articular fluid from patient with prosthesis & AMX, AMC, CFZ, CLI, CLOX, ERY, GEN, RIF \\
\hline
\end{tabular}

a Resistance to antibiotics was analyzed by diffusion discs on agar by Hospital Universitario Donostia.

${ }^{b} A M X$, amoxicillin; AMC, amoxicillin + clavulanic acid; CFZ, cefazolin; CLI, clindamycin; CLOX, cloxacillin; CTX, cotrimoxazol; ERY, erythromycin; GEN, gentamicin; LVX, levofloxacin; MUP, mupirocin; RIF, rifampicin; TET, tetracycline; VAN, vancomycin.

Madrid, Spain). Bands were visualized by ChemiDoc XRS System (BioRad). Images were analyzed by Quantity One 1-D Analysis Software (BioRad).

\section{Polymerase Chain Reaction (PCR) and Southern Blotting}

PCR and Southern blotting assays, specific for horizontal transfer and antibiotic resistance genes, were performed using the strains and plasmids indicated in Table 2 as reference DNA. Oligonucleotides used for gene detection are listed in Table 3. Each $25 \mu \mathrm{l}$ PCR reaction mixture contained $1.25 \mathrm{U}$ Taq polymerase (New England Biolabs, Ipswich, U.S.), $1 \times$ PCR buffer, $0.5 \mu \mathrm{M}$ of each primer, $0.2 \mathrm{mM}$ deoxynucleoside triphosphates and $20 \mathrm{ng}$ of template DNA (plasmid DNA). Amplifications were carried out in a $\mathrm{C} 1000^{\mathrm{TM}}$ Thermal Cycler (BioRad). PCR temperature profiles are shown in Table 4. PCR products were separated by agarose gel electrophoresis, transferred to a membrane (Sambrook and Russel, 2001), and then hybridized with the corresponding specific DIGlabeled probe using the PCR DIG Probe Synthesis Kit (Roche, Mannheim, Germany). Detection of DNA sequences was performed with the DIG Luminescent Detection Kit (Roche) according to the manufacturer's instructions.
TABLE 2 | Bacterial strains and plasmids used as reference for PCR and Southern blotting.

\begin{tabular}{|c|c|c|}
\hline Strain & Characteristics & References \\
\hline \multicolumn{3}{|c|}{ Bacillus subtilis } \\
\hline BD662 & pBD90, ermD & Gryczan et al., 1984 \\
\hline BD1156 & pBD370, ermG & Monod et al., 1987 \\
\hline \multicolumn{3}{|c|}{ Enterococcus faecalis } \\
\hline RE25 & pRE25, ermB, tetM & Schwarz et al., 2001 \\
\hline V583 & pTEF1, pTEF2, pTEF3, vanB & Paulsen et al., 2003 \\
\hline \multicolumn{3}{|c|}{ S. aureus } \\
\hline RN3259 & pT181, tetK, pre $\mathrm{pT}_{181}$ & Khan et al., 1981 \\
\hline SK5428 & $\begin{array}{l}\text { pSK41, acc }\left(6^{\prime}\right)-l e-a p h\left(2^{\prime}\right)-l a, \text { tra }^{+}, \text {pre } \text { pSK } 41_{1} \\
\text { nespSK41 }\end{array}$ & Firth et al., 1993 \\
\hline \multicolumn{3}{|c|}{ S. haemolyticus } \\
\hline VPS617 & tetK, ermC & Perreten et al., 2005 \\
\hline
\end{tabular}

\section{Biofilm Formation}

To test the 25 clinical isolates for biofilm formation, a quantitative adherence assay (Christensen et al., 1985) with some modifications was used. Briefly, $200 \mu \mathrm{l}$ of TSB medium 
TABLE 3 | Oligonucleotides used for the detection of antibiotic resistance and transfer genes.

\begin{tabular}{|c|c|c|c|c|c|}
\hline Gene & Oligonucleotide & Sequence $\left(5^{\prime} \rightarrow 3^{\prime}\right)$ & Acc. Noa & $\begin{array}{l}\text { Nucleotide } \\
\text { position }\end{array}$ & Reference \\
\hline \multirow[t]{5}{*}{$\begin{array}{l}\text { Antibiotic resistance } \\
\text { genes }\end{array}$} & $\begin{array}{l}\text { aac6-aph2a fw } \\
\text { aac6-aph2a rev }\end{array}$ & $\begin{array}{l}\text { GCCAGAACATGAATTACACGAG } \\
\text { CTGTTGTTGCATTTAGTCTITCC }\end{array}$ & NC_005024 & $\begin{array}{l}42,981-43,002 \\
43,569-43,591\end{array}$ & Schiwon et al., 2013 \\
\hline & $\begin{array}{l}\text { ermB fw } \\
\text { ermB rev }\end{array}$ & $\begin{array}{l}\text { GCATTTAACGACGAAACTGGCT } \\
\text { GACAATACTTGCTCATAAGTAATGGT }\end{array}$ & U00453 & $\begin{array}{l}6,796-6,817 \\
7,343-7,368\end{array}$ & Böckelmann et al., 2009 \\
\hline & $\begin{array}{l}\text { ermC fw } \\
\text { ermC rev }\end{array}$ & $\begin{array}{l}\text { CGTAACTGCCATTGAAATAGACC } \\
\text { TCCTGCATGTITAAGGAATTG }\end{array}$ & V01278 & $\begin{array}{l}2,555-2,577 \\
2,079-2,100\end{array}$ & Schiwon et al., 2013 \\
\hline & $\begin{array}{l}\text { ermG fw } \\
\text { ermG rev }\end{array}$ & $\begin{array}{l}\text { TGCAGGGAAAGGTCATITAC } \\
\text { AACCCATTCATTACAAAAGTTC }\end{array}$ & M15332 & $\begin{array}{c}785-805 \\
1,245-1,268\end{array}$ & Schiwon et al., 2013 \\
\hline & $\begin{array}{l}\text { tetK fw } \\
\text { tetK rev }\end{array}$ & $\begin{array}{l}\text { TTGAGCTGTCTTGGTTCATTG } \\
\text { AGCCCACCAGAAAACAAACC }\end{array}$ & CP000045 & $\begin{array}{l}1,398-1,419 \\
1,918-1,937\end{array}$ & Schiwon et al., 2013 \\
\hline \multirow[t]{6}{*}{ Transfer genes } & $\begin{array}{l}\text { pSK41 pre fw } \\
\text { pSK41 pre rev }\end{array}$ & $\begin{array}{l}\text { CTGGACTAAAAGGCATGCAA } \\
\text { GCAGTITCCATCACGCATA }\end{array}$ & AF051917 & $\begin{array}{l}20,674-20,693 \\
20,298-20,317\end{array}$ & Schiwon et al., 2013 \\
\hline & $\begin{array}{l}\text { pSK41 nes fw } \\
\text { pSK41 nes rev }\end{array}$ & $\begin{array}{l}\text { AGCGCTAGTAGGATTAAAG } \\
\text { CATAATAAATGTGCGTGAGG }\end{array}$ & AF051917 & $\begin{array}{c}10,016-10,034 \\
9,706-9,725\end{array}$ & Schiwon et al., 2013 \\
\hline & $\begin{array}{l}\text { PT181 pre fw } \\
\text { pT181 pre rev }\end{array}$ & $\begin{array}{l}\text { TCGAACAGAATTATACAGGCAA } \\
\text { CTGACTTATTTGCTCATGTTAAC }\end{array}$ & CP000045 & $\begin{array}{l}2,708-2,729 \\
3,082-3,105\end{array}$ & Schiwon et al., 2013 \\
\hline & $\begin{array}{l}\text { traE pSK41 fw } \\
\text { traE pSK41 rev }\end{array}$ & $\begin{array}{l}\text { TATCATTGATCC(T/C)GAA(A/G)ATGAAT } \\
\text { TCTITGT(T/G)ATTTCGTCCCATAA }\end{array}$ & AF051917 & $\begin{array}{l}27,456-27,478 \\
28,060-28,082\end{array}$ & Schiwon et al., 2013 \\
\hline & $\begin{array}{l}\text { traG pSK41 fw } \\
\text { traG pSK41 rev }\end{array}$ & $\begin{array}{l}\text { GTGTTGACGGTTCGGGTATC } \\
\text { TITCCGTCTGAACCTCCAC }\end{array}$ & AF051917 & $\begin{array}{l}30,132-30,151 \\
30,570-30,589\end{array}$ & Schiwon et al., 2013 \\
\hline & $\begin{array}{l}\text { traK pSK41 fw } \\
\text { traK pSK41 rev }\end{array}$ & $\begin{array}{l}\text { TATCTAAAGACCACCCAGCTAGAG } \\
\text { TACTTGTTCAAACTCTACAGTAGC }\end{array}$ & AF051917 & $\begin{array}{r}34,636-34,660 \\
35,185-35209\end{array}$ & Schiwon et al., 2013 \\
\hline
\end{tabular}

${ }^{a}$ Accession Number from Gene Bank.

TABLE 4 | PCR conditions.

\begin{tabular}{|c|c|c|c|}
\hline Genes amplified & Denaturation & $\begin{array}{l}\text { Primer } \\
\text { annealing }\end{array}$ & Elongation \\
\hline aac6-aph2a, ermD, ermG, & $95^{\circ} \mathrm{C}, 30 \mathrm{~s}$ & $55^{\circ} \mathrm{C}, 30 \mathrm{~s}$ & $72^{\circ} \mathrm{C}, 30 \mathrm{~s}$ \\
\hline ermC, tetK, tetM & $95^{\circ} \mathrm{C}, 30 \mathrm{~s}$ & $58^{\circ} \mathrm{C}, 30 \mathrm{~s}$ & $72^{\circ} \mathrm{C}, 30 \mathrm{~s}$ \\
\hline ermB, vanB & $95^{\circ} \mathrm{C}, 30 \mathrm{~s}$ & $60^{\circ} \mathrm{C}, 45 \mathrm{~s}$ & $72^{\circ} \mathrm{C}, 60 \mathrm{~s}$ \\
\hline traE, traG, traK, traL, traM, pre & $95^{\circ} \mathrm{C}, 30 \mathrm{~s}$ & $55^{\circ} \mathrm{C}, 45 \mathrm{~s}$ & $72^{\circ} \mathrm{C}, 60 \mathrm{~s}$ \\
\hline pre $_{p S K 41}$, nes $_{p S K 41}$ & $95^{\circ} \mathrm{C}, 60 \mathrm{~s}$ & $50^{\circ} \mathrm{C}, 60 \mathrm{~s}$ & $72^{\circ} \mathrm{C}, 120 \mathrm{~s}$ \\
\hline
\end{tabular}

An initial denaturation step was performed, consisting of $2 \mathrm{~min}$ at $95^{\circ} \mathrm{C}$, except for pre $_{p S K 41}$, nespSK41, that were denaturated for $4 \mathrm{~min}$. Then, 30 cycles consisting of denaturation, primer annealing and elongation steps were performed at the conditions (temperature and time) specified. A final elongation step at $72^{\circ} \mathrm{C}$ was performed during $5 \mathrm{~min}$, except for pre ${ }_{p S K 41}$, nes pSK $41_{1}$ in which it lasted $10 \mathrm{~min}$.

in 96-well flat-bottom polystyrene plates were inoculated with $10 \mu \mathrm{l}$ overnight bacterial cultures and grown without shaking at $37^{\circ} \mathrm{C}$ for $24 \mathrm{~h}$. Planktonic bacteria were removed from each well. Then, three washes with distilled water per well were carried out. Next, $125 \mu \mathrm{l}$ of $0.1 \%$ (w/v) crystal violet solution were added to each well and incubated for $10 \mathrm{~min}$ at room temperature. Subsequently, three washes with distilled water were again performed. To solubilize the dye, $200 \mu \mathrm{l}$ of $33 \%(\mathrm{v} / \mathrm{v})$ glacial acetic acid solution were added to each stained well and incubated for $10 \mathrm{~min}$ at room temperature. TSB medium was used as negative control. The optical density of the attached bacteria was measured in a microplate reader at $570 \mathrm{~nm}$ (in triplicate for each strain). The ability to form biofilm was attributed as: $\mathrm{OD}_{570}<0.120$, no biofilm-forming; $0.120<\mathrm{OD}_{570}<0.240$, weak biofilm-forming; $\mathrm{OD}_{570}>$ 0.240, strong biofilm-forming (Christensen et al., 1985; Di Rosa et al., 2006); and $\mathrm{OD}_{570}>1.5$, very strong biofilm-forming. Dilutions were performed when absorbance values were higher than the limit of accurate detection. To classify the isolates into significant groups, statistical analysis was performed using SigmaPlot program and Student's $t$-test or Mann-Whitney U-test. 


\section{RESULTS}

\section{All Clinical Isolates, Except One, Harbored Plasmids}

Plasmid DNA was extracted from the 25 clinical isolates and then analyzed by agarose gel electrophoresis and PFGE (Figures 1, 2). Since plasmid DNA samples are sometimes contaminated with chromosomal DNA, as suggested in Figure 1 for some of our isolates (i.e., 1, 3, 17, 21), after the extraction of plasmid DNA, we decided to test for such contamination. To this purpose, 16S rRNA from isolates 1, 3, 17, and 21 was amplified by PCR as explained in Broszat et al. (2014). The obtained amplicons were analyzed by $1 \%(\mathrm{w} / \mathrm{v})$ agarose gel electrophoresis in $1 \times$ TAE buffer. As observed in Supplementary Figure 1, some of our plasmid DNA samples appear to be contaminated with chromosomal DNA. Nonetheless, as reflected in Figures 1, 2, the majority of the extracted DNA corresponds to plasmid DNA.

As shown in Figures 1, 2 and Table 5, a total of 54 plasmids of sizes ranging from 2 to $200 \mathrm{~kb}$ were detected using both methods: 15 small plasmids (size $<20 \mathrm{~kb}$ ) and 39 large plasmids (size $>$ $20 \mathrm{~kb}$; Shearer et al., 2011). All clinical isolates contained at least one plasmid, except isolate 3. The combination of agarose gel electrophoresis and PFGE is unable to detect plasmids between 13 and $45 \mathrm{~kb}$. Then, a priori, our clinical isolates could harbor more plasmids than observed here. In particular, isolate 3 could harbor a plasmid between 13 and $45 \mathrm{~kb}$, which could explain the apparent lack of plasmid observed for this isolate.

When agarose gel electrophoresis was used, it was observed that $44 \%$ of the clinical isolates contained at least one plasmid with a size $<20 \mathrm{~kb}$ (Figure 1 and Table 5). In particular, nine of the isolates contained only one plasmid smaller than $20 \mathrm{~kb}$.

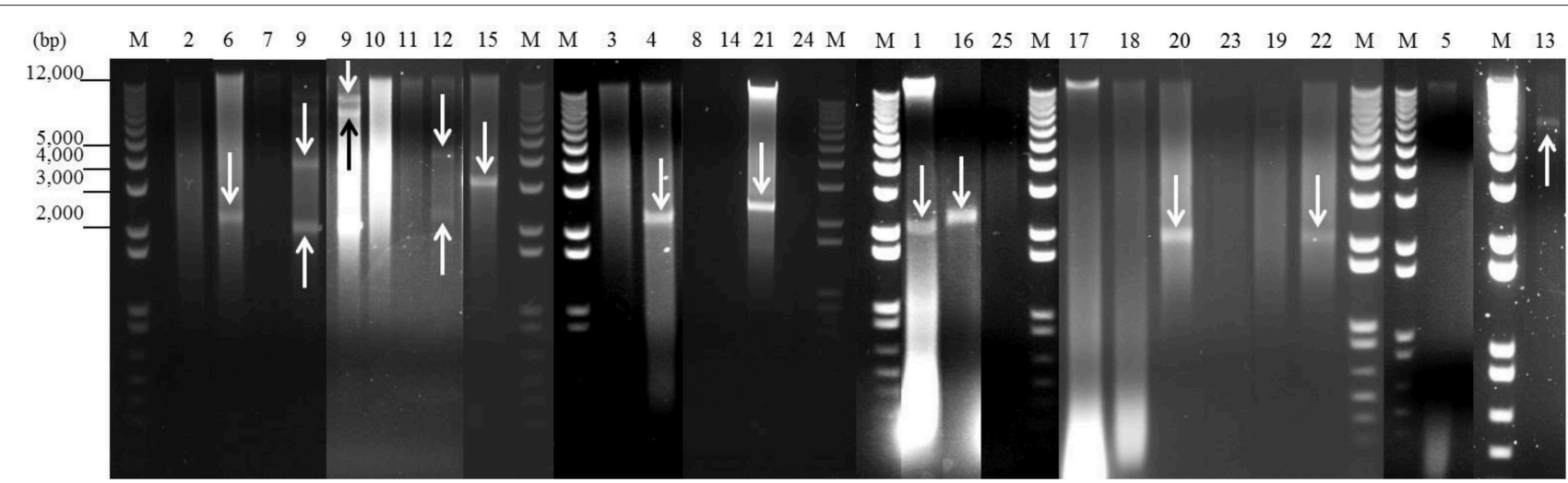

FIGURE 1 | Detection of plasmids from 25 staphylococcal clinical isolates by agarose gel electrophoresis after digestion with nuclease S1. One microgram of plasmid DNA from each isolate was digested with $30 \mathrm{U}$ of nuclease $\mathrm{S} 1$ at $37^{\circ} \mathrm{C}$ for $45 \mathrm{~min}$. After digestion, the plasmids were analyzed by $1 \%$ (w/v) agarose gel electrophoresis in $1 \times$ TAE buffer. Lanes 1-25: digested plasmid DNA from each strain (lane numbers correspond to the number of the isolate). Lanes M: DNA molecular weight marker $1 \mathrm{~kb}$ Plus DNA Ladder. Bands corresponding to plasmids are indicated with arrows.

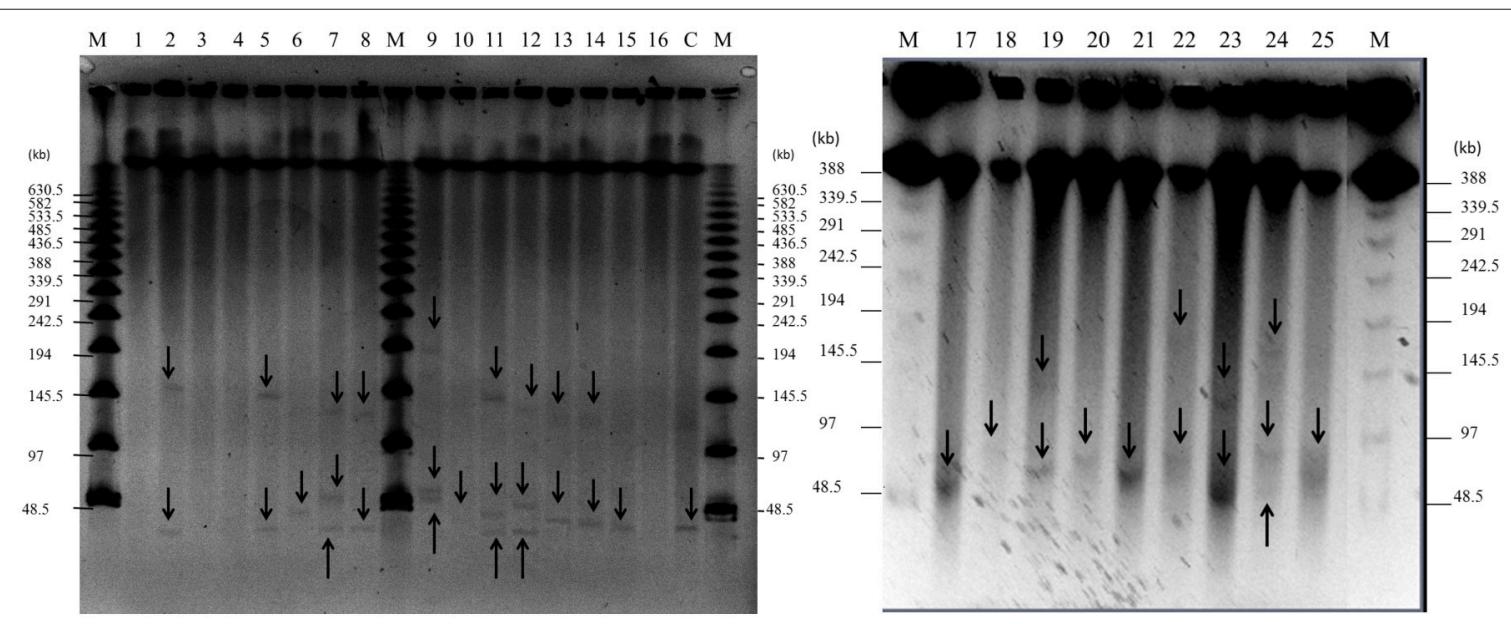

FIGURE 2 | Detection of plasmids in 25 staphylococcal clinical isolates by PFGE. Large plasmids (>30 kb) were analyzed by PFGE after digestion with nuclease S1 at $37^{\circ} \mathrm{C}$ for $45 \mathrm{~min}$. Lanes 1-25: clinical isolates; lane number corresponds to the number of the isolate. Lane C: positive control, plasmid pSK41 (46.4 kb) extracted from SK5428 strain. Lane M: Lambda Ladder PFGE molecular size marker. Arrows point to detected plasmids. 
TABLE 5 | Antibiotic resistance profiles, transfer genes, plasmid content, and biofilm-forming capacity of staphylococcal clinical isolates.

\begin{tabular}{|c|c|c|c|c|c|c|}
\hline \multirow[t]{2}{*}{ Isolate } & \multirow{2}{*}{$\begin{array}{l}\text { Antibiotic resistance } \\
\text { phenotype }^{\mathrm{a}}\end{array}$} & \multirow[t]{2}{*}{ Antibiotic resistance genotype ${ }^{b}$} & \multirow[t]{2}{*}{ Transfer genes } & \multicolumn{2}{|c|}{ Plasmids ${ }^{c}$} & \multirow{2}{*}{$\begin{array}{l}\text { Biofilm-forming } \\
\text { capacity } 24 h^{d}\end{array}$} \\
\hline & & & & $<20 \mathrm{~kb}$ & $b>20 \mathrm{~kb}$ & \\
\hline 1 & ERY & ermB, ermC, tetK, aac6-aph2a & pre $_{\mathrm{pSK} 41}$, nes $_{\mathrm{pSK} 41}$, pre $\mathrm{pT}_{181}$, traE, traG, traK, traL, traM* & 1 & 0 & 0 \\
\hline 2 & GEN & ermB, ermC, ermG, tetK, aac6-aph2a & pre $_{\mathrm{pSK} 41}$, pre $\mathrm{pT181}$, traG, traL & 0 & 2 & 1 \\
\hline 3 & ERY & ermC, tetK, aac6-aph2a & pre $_{\mathrm{pSK} 41}$, pre $_{\mathrm{pT} 181}, \operatorname{traL}^{*}$ & 0 & 0 & 1 \\
\hline 4 & ERY & ermB*, ermC, tetK, aac6-aph2a & pre $_{\mathrm{pSK} 41}$, nes $_{\mathrm{pSK} 41}$, pre $_{\mathrm{pT} 181}$, traL & 1 & 0 & 0 \\
\hline 5 & - & ermB, ermC, tetK*, aac6-aph2a* & pre $_{\mathrm{pSK} 41}$, pre $\mathrm{pr}_{181}$, traK, traL & 0 & 2 & 3 \\
\hline 6 & ERY, GEN & ermB, ermC, tetK, aac6-aph2a & pre $_{\mathrm{pSK} 41}$, pre $\mathrm{pT}_{181}$, traG, traK, traL & 1 & 1 & 2 \\
\hline 7 & ERY, GEN & ermB, ermC, tetK, aac6-aph2a & pre $_{\mathrm{pSK} 41}$, nes $_{\mathrm{pSK} 41}$, pre $_{\mathrm{pT} 181}$, traE, traK, traL & 0 & 3 & 2 \\
\hline 8 & GEN & ermC, tetK*, aac6-aph2a & pre $_{\mathrm{pSK} 41}$, nes $_{\mathrm{pSK} 41}$, pre $_{\mathrm{pT} 181}$, traG, traK & 0 & 2 & 3 \\
\hline 9 & ERY, TET & ermC, tetK* & pre $_{\mathrm{pSK} 41^{*}}{ }^{*}$ pre $\mathrm{pT}_{181}$, traL $^{*}$ & 4 & 3 & 2 \\
\hline 10 & ERY & ermB, ermC, tetK, aac6-aph2a, vanB & pre $_{\mathrm{pSK} 41}$, pre $_{\mathrm{pT} 181}$, traG, traL & 0 & 1 & 2 \\
\hline 11 & - & ermB, ermC, tetK & pre $_{\mathrm{pSK} 41}$, nes $_{\mathrm{pSK} 41}$, pre $_{\mathrm{pT} 181}$, traE, traG, traL, traM & 0 & 3 & 1 \\
\hline 12 & ERY, GEN, TET & ermC, tetK, aac6-aph2a & pre $_{\mathrm{pSK} 41}{ }^{*}$, pre $_{\mathrm{pT} 181}$, traG $^{\star}$, traL & 2 & 3 & 3 \\
\hline 13 & GEN & ermB, ermC, tetK, aac6-aph2a & pre $_{\mathrm{pSK} 41}$, pre $_{\mathrm{pT} 181}, \operatorname{tra}^{*}, \operatorname{traG}^{*}$, traK, $\operatorname{tra}^{*}$, traM ${ }^{*}$ & 1 & 2 & 2 \\
\hline 14 & - & ermC, tetK*, aac6-aph2a & pre $_{\mathrm{p} T 181}$, traE, traG ${ }^{\star}$, traK, traL & 0 & 2 & 0 \\
\hline 15 & ERY & ermB, ermC, ermG*, tetK, aac6-aph2a & pre $_{\mathrm{pSK} 41}$, pre $_{\mathrm{pT} 181}$, traL $^{*}$ & 1 & 1 & 1 \\
\hline 16 & ERY & ermB, ermC, tetK, aac6-aph2a & pre $_{\mathrm{pSK} 41}$, nes $_{\mathrm{pSK} 41}$, pre $_{\mathrm{pT} 181}$, traE $E^{*}$, traG ${ }^{*}$, traK, traL & 1 & 0 & 0 \\
\hline 17 & ERY & ermB, ermC, tetK, aac6-aph2a & pre $_{\mathrm{pSK} 41}$, nes $_{\mathrm{pSK} 41}$, pre $_{\mathrm{pT} 181}$, traE, traG, traK, traL, traM & 0 & 1 & 2 \\
\hline 18 & - & ermB*, ermC, tetK, aac6-aph2a & pre $_{\mathrm{pSK} 41}$, nes $_{\mathrm{pSK} 41}$, pre $\mathrm{pr}_{\mathrm{p} 181}$, traE, traG, traK, traL & 0 & 1 & 0 \\
\hline 19 & - & ermC, tetK, aac6-aph2a & pre $_{\mathrm{pSK} 41}$, pre $_{\mathrm{p} T 181}$, traK $^{\star}$, traM & 0 & 2 & 2 \\
\hline 20 & ERY, GEN & ermB ${ }^{\star}$, ermC, tetK, aac6-aph2a & pre $_{\mathrm{pSK} 41}$, pre $_{\mathrm{p} T 181}$, traE $E^{\star}, \operatorname{traG}^{\star}$, traK $K^{\star}$, traL, traM & 1 & 1 & 2 \\
\hline 21 & ERY, GEN & ermB*, ermC, tetK & pre $_{\mathrm{pSK} 41}$, pre $_{\mathrm{pT} 181}$, traE, traG, traK, traL, traM & 1 & 1 & 2 \\
\hline 22 & - & ermB, ermC, tetK, aac6-aph2a & pre $_{\mathrm{pSK} 41}$, pre $_{\mathrm{pT} 181}, \operatorname{traE}^{\star}$, traG ${ }^{\star}$, traL, traM & 1 & 2 & 3 \\
\hline 23 & ERY, GEN & ermC, aаc6-aph2a & pre $_{\mathrm{pSK} 41}$, pre $_{\mathrm{pT} 181}$, traE $^{\star}$, traG, traL & 0 & 2 & 2 \\
\hline 24 & GEN & ermB*, ermC, aac6-aph2a & pre $_{\mathrm{pSK} 41}$, pre $_{\mathrm{pT} 181}$ & 0 & 3 & 2 \\
\hline 25 & ERY, GEN & ermB, ermC, tetK, tetM, aac6-aph2a & pre $_{\mathrm{pSK} 41}$, pre $_{\mathrm{pT} 181}$, traG ${ }^{\star}$, traK $K^{\star}$, traL, traM & 0 & 1 & 3 \\
\hline
\end{tabular}

${ }^{a} G E N$, gentamicin; ERY, erythromycin; TET, tetracycline.

baac6-aph2a, gentamicin; ermB/erm C/ermG, erythromycin; tetK/tetM, tetracycline; vanB, vancomycin resistance genes.

${ }^{c}$ Numbers indicate the number of plasmid bands observed in the $1 \%$ agarose gel or in the PFGE.

${ }^{d} 0$, no biofilm-forming capacity; 1, weak biofilm-forming capacity; 2, strong biofilm-forming capacity, 3, very strong biofilm-forming capacity.

*Weak signal intensity in the Southern blot.

Isolate 12 harbored two plasmids smaller than $20 \mathrm{~kb}$, while 4 plasmids of this size were identified in isolate 9.

According to our PFGE data, 84\% of the clinical isolates (all except isolates 1, 3, 4, and 16) contained at least one large plasmid (Figure 2 and Table 5): 32\% of the isolates (6, 10, 15, 17, 18, 20, 21 , and 25$)$ harbored one large plasmid; $32 \%$ of the isolates $(2,5$, $8,13,14,19,22$, and 23) contained two large plasmids; and $20 \%$ of the isolates $(7,9,11,12$, and 24) harbored three large plasmids.

\section{All Clinical Isolates Contained Antibiotic Resistance Genes}

Eight resistance genes commonly found in staphylococci were investigated by PCR and Southern blotting: genes encoding resistance to erythromycin $(\operatorname{erm} B, \operatorname{erm} C$, ermD, erm $G$ ), tetracycline (tet $K$, tet $M$ ), gentamicin (aac6-aph $2 a$ ), and vancomycin $(v a n B)$. The presence of these genes was tested in our extracted DNA (i.e., putative plasmid DNA) because, initially, we were only interested in the risk of dissemination of antibiotic resistance from these clinical strains through bacterial conjugation.
Concerning erythromycin resistance, 15 of the strains had an erythromycin resistance phenotype (Table 1). Data at the genotype level for the different clinical isolates are shown in Table 5. ermC gene was observed in all the isolates (Figure 3), while ermD was not detected in any of the isolates (Supplementary Figure 2). Likewise, $72 \%$ of the isolates were ermB-positive (Supplementary Figure 3), whereas only $8 \%$ of the isolates (2 and 15) harbored the erm $G$ gene (Supplementary Figure 4).

With respect to tetracycline, only two isolates (9 and 12) were observed to be tetracycline resistant at the phenotype level (Table 1). Regarding this antibiotic, 23 out of 25 isolates contained the tetK gene (Supplementary Figure 5), while only isolate 25 harbored the tet $M$ gene (Supplementary Figure 6).

Similarly, the 25 isolates were analyzed for the occurrence of the gentamicin resistance aac6-aph $2 a$ gene. As shown in Supplementary Figure 7, this gene was detected in $88 \%$ of the isolates (all the isolates except 9, 11, and 21 showed a positive result for the aac6-aph $2 a$ gene). However, according to the phenotype (Table 1), only $44 \%$ of the isolates showed gentamicin resistance. 


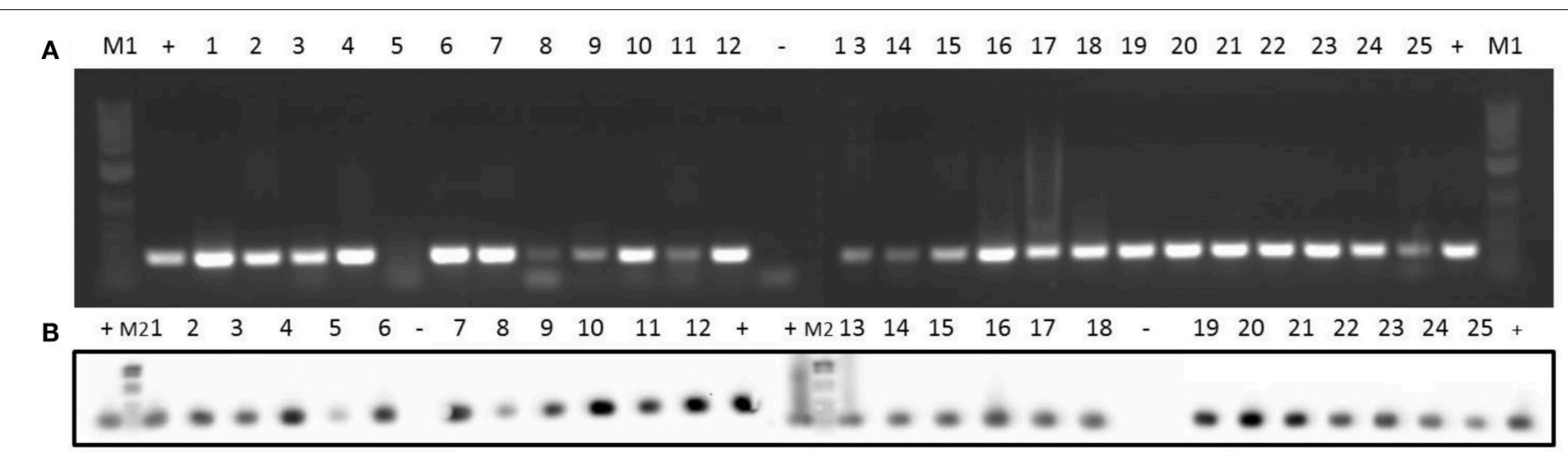

FIGURE 3 | Detection of erythromycin resistance gene ermC in 25 clinical isolates by PCR (A) and Southern blotting (B). Amplicons of ermC (477 bp) were visualized on 1\% (w/v) agarose gels. Lanes 1-25: clinical isolates. Lanes +: positive control. Lanes -: negative control. Lanes M1: DNA molecular weight marker 1 kb Plus DNA Ladder. Lanes M2: DNA molecular weight marker VI DIG-labeled.

Finally, regarding vancomycin resistance, all the isolates were phenotypically sensitive to this antibiotic (Table 1). At the genotype level, only isolate 10 proved to be $v a n B$-positive (Figure 4).

\section{All Clinical Isolates Encoded Relaxase and/or Horizontal Transfer Genes Commonly Found in Staphylococcus Conjugative/Mobilizable Plasmids}

In order to find out whether the abovementioned antibiotic resistance genes were likely to be disseminated via conjugative transfer, we searched for horizontal transfer genes from two common staphylococcal plasmids: (i) conjugative pSK41 and (ii) mobilizable pT181 (Novick, 1989; Berg et al., 1998).

In relation to pSK41, the pre relaxase gene was found in all the isolates except isolate 14 (Supplementary Figure 8). In addition, isolates $1,4,7,8,11,16,17$, and 18 contained the nes relaxase gene of pSK41 (Supplementary Figure 9). Five genes (traE, traG, traK, traL, and traM) from the transfer region of pSK41 were also analyzed: traE gene was present in $48 \%$ of the isolates (Supplementary Figure 10), traG gene was detected in $68 \%$ of the isolates (Supplementary Figure 11), traK gene was found in 56\% of the isolates (Figure 5), and traL gene was detected in $88 \%$ of the isolates (Supplementary Figure 12). Finally, traM gene was found in only $36 \%$ of the isolates (Supplementary Figure 13).

In addition, we tested for the presence of the pre relaxase gene of the staphylococcal mobilizable plasmid pT181. As shown in Figure 6, this gene was detected in all the clinical isolates.

\section{Clinical Isolates Differed in their Biofilm-Forming Capacity}

All the clinical strains were isolated from biofilms formed on medical devices such as catheters and prostheses, as well as from ulcer and articular fluids from patients with prostheses (Table 1). In order to confirm their biofilm forming capacity, we used the in vitro assay described above (Christensen et al., 1985; Di Rosa et al., 2006).
As shown in Figure 7, isolates were divided into four groups: (i) no biofilm-forming isolates: 1, 4, 14, 16, 18; (ii) weak biofilm-forming isolates: 2, 3, 11, 15; (iii) strong biofilm-forming isolates: $6,7,9,10,13,17,19,20,21,23,24$; and (iv) very strong biofilm-forming isolates: 5, 8, 12, 22, 25. Additionally, our statistical analysis showed that the "strong biofilm-forming" group could be further divided into three different sub-groups with increasing biofilm forming capacity from "strong biofilmforming (1)" to "strong biofilm-forming (3)." The distribution of isolates in these three sub-groups was as follows: "strong biofilmforming (1)": 7, 10, 17, 23; “strong biofilm-forming (2)": 9, 19; and "strong biofilm-forming (3)": 6, 13, 20, 21, 24 (Figure 7). Furthermore, the relationship between biofilm-forming capacity and Staphylococcus species was studied. S. epidermidis isolates had a significantly higher $(p<0.001)$ biofilm-forming capacity than $S$. aureus isolates.

\section{DISCUSSION}

Staphylococci nosocomial pathogens are frequently involved in biomaterial-associated infections (Pfaller and Herwaldt, 1988; Kloos and Bannerman, 1994; Huebner and Goldmann, 1999; Otto, 2008). The eradication of these biofilm-associated infections with antibiotic treatment is usually impossible without the removal of the medical device (Stewart and Costerton, 2001; Mack et al., 2004; Otto, 2012; Tong et al., 2012). Furthermore, conjugative plasmid-mediated dissemination of antibiotic resistance is favored in bacterial biofilms (Ghigo, 2001; Molin and Tolker-Nielsen, 2003; Reisner et al., 2006; Yang et al., 2008; D’Alvise et al., 2010).

In this work, 25 staphylococcal biofilm-forming clinical isolates were studied. First, plasmids of different sizes were detected. Secondly, antibiotic resistance and transfer genes were detected by PCR and Southern blotting. Finally, the capacity of these isolates to form biofilms in vitro was studied.

Fifteen plasmids smaller than $20 \mathrm{~kb}$ and 39 plasmids larger than $20 \mathrm{~kb}$ were found in 11 (44\%) and 21 (84\%) isolates, respectively. This higher percentage of isolates with large 


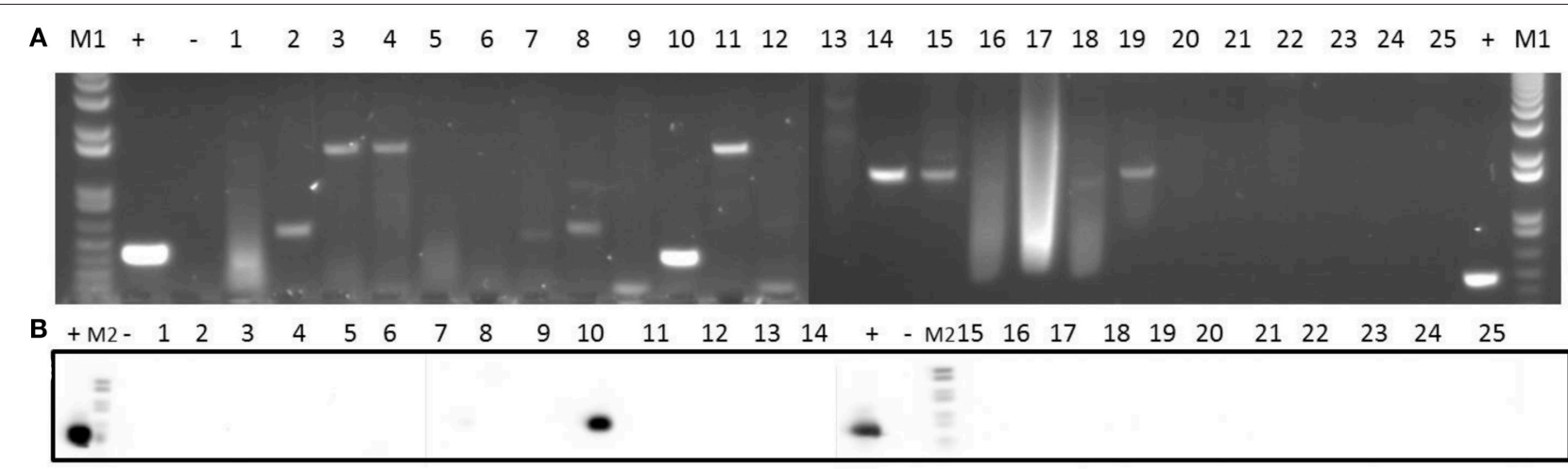

FIGURE 4 | Detection of vancomycin resistance gene vanB in 25 clinical isolates by PCR (A) and Southern blotting (B). Amplicons of vanB (539 bp) were visualized on $1 \%(\mathrm{w} / \mathrm{v})$ agarose gels. Lanes 1-25: clinical isolates. Lanes +: positive control. Lanes -: negative control. Lanes M1: DNA molecular weight marker 1 kb Plus DNA Ladder. Lanes M2: DNA molecular weight marker VI DIG-labeled.

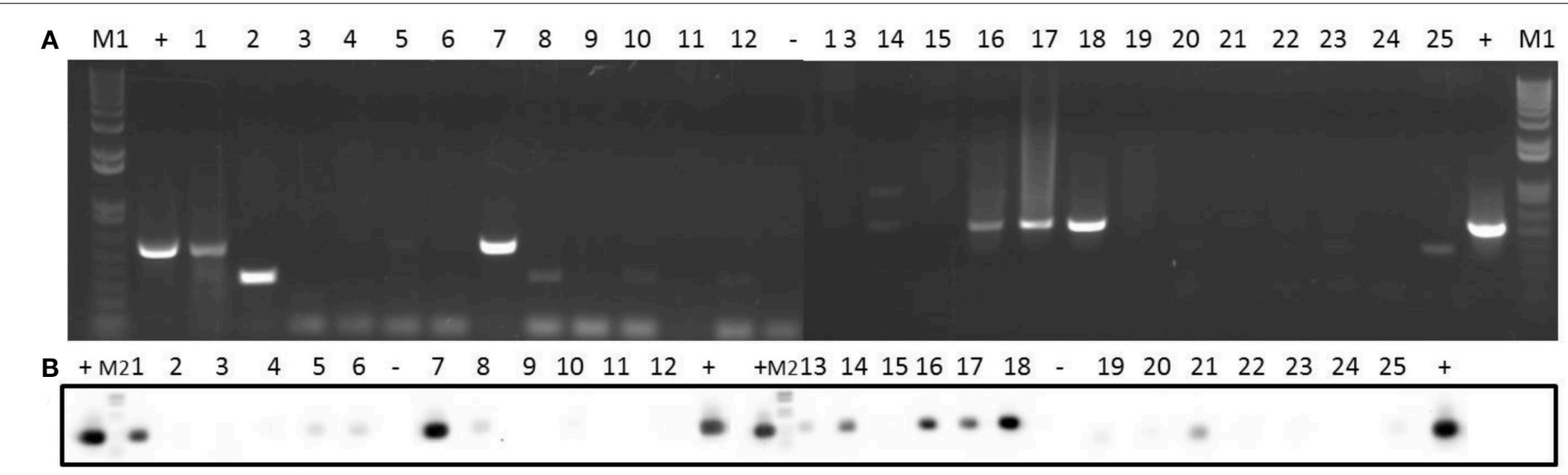

FIGURE 5 | Detection of traK gene in 25 clinical isolates by PCR (A) and Southern blotting (B). Amplicons of traK gene (573 bp) were visualized on $1 \%$ (w/v) agarose gels. Lanes 1-25: clinical isolates. Lanes +: positive control. Lanes -: negative control. Lanes M1: DNA molecular weight marker 1 kb Plus DNA Ladder. Lanes M2: DNA molecular weight marker VI DIG-labeled.

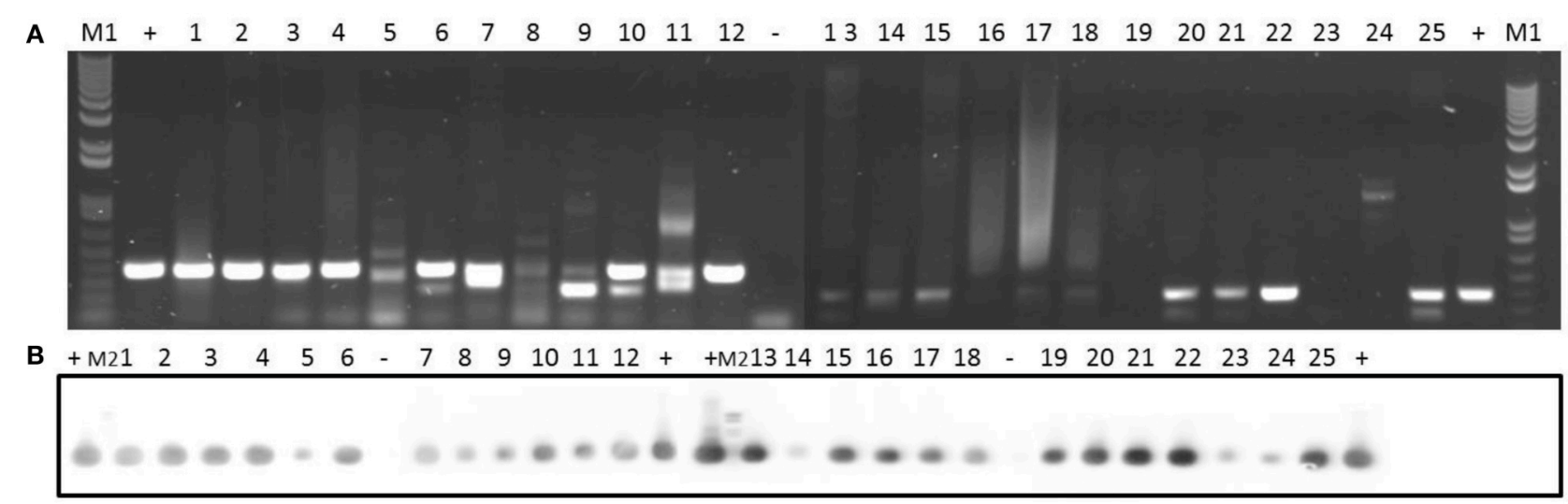

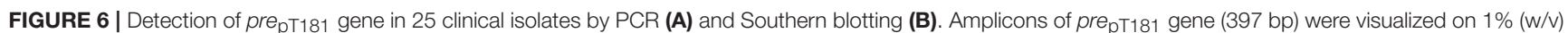
agarose gels. Lanes 1-25: clinical isolates. Lanes +: positive control. Lanes -: negative control. Lanes M1: DNA molecular weight marker 1 kb Plus DNA Ladder. Lanes M2: DNA molecular weight marker VI DIG-labeled. 

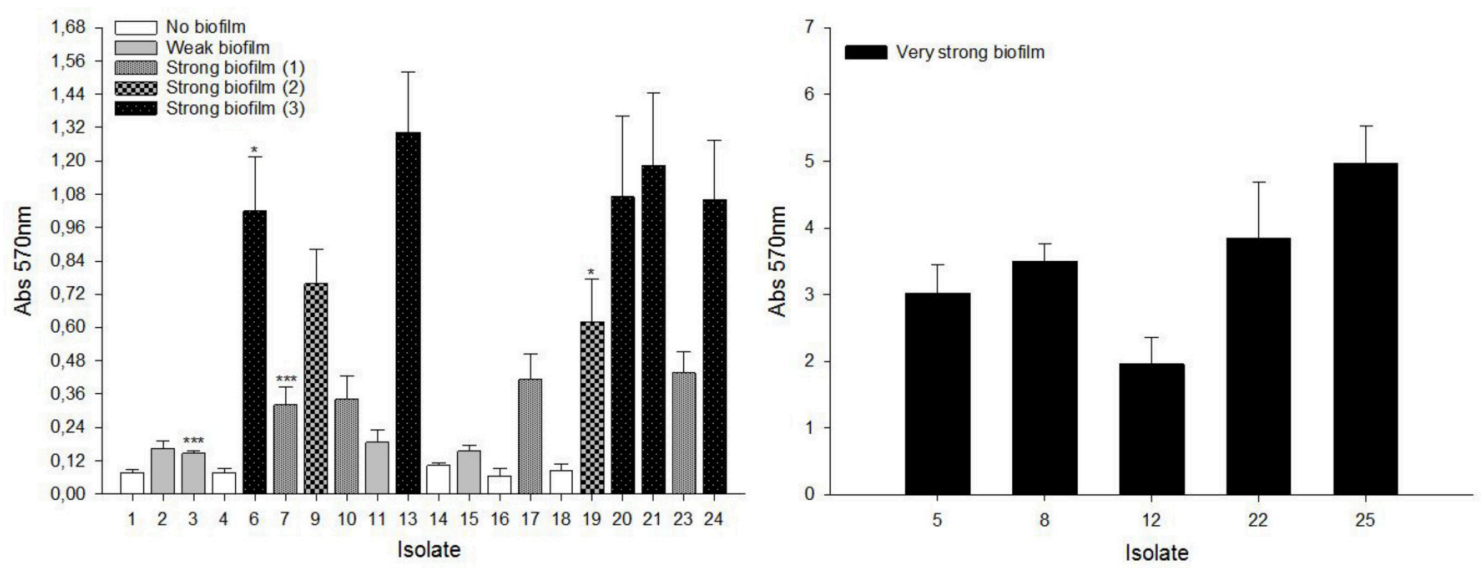

FIGURE 7 | Biofilm-forming capacity of staphylococcal clinical isolates. 96-well flat-bottom polystyrene plates were incubated for $24 \mathrm{~h}$ at $37^{\circ} \mathrm{C}$ without shaking. Cells attached to the wells were stained with $0.1 \%(\mathrm{w} / \mathrm{v})$ crystal violet. Absorption at $570 \mathrm{~nm}$ was measured to quantify biofilm formation. Results are the mean \pm SEM of at least 4 independent biological experiments performed in triplicate. To classify the isolates into significant groups, statistical analysis was performed using Student's

$t$-test or Mann-Whitney $U$-test $\left({ }^{*} p<0.05,{ }^{* \star *} p<0.001\right)$.

plasmids, compared to isolates with small plasmids, is in agreement with results obtained by Shearer et al. (2011) who found that $79 \%$ of their isolates harbored at least one large ( $>20 \mathrm{~kb})$ plasmid. According to Smillie et al. (2010), in proteobacteria, $58 \%$ of the plasmids larger than $20 \mathrm{~kb}$ are mobilizable. Therefore, our results suggest that almost all our Staphylococcus clinical isolates could harbor conjugative and/or mobilizable plasmids.

On the other hand, the presence of antibiotic resistance and horizontal transfer genes commonly found staphylococci was investigated. Antibiotic sensitivity tests (to obtain the well-known antibiograms) are the most common method to determine antibiotic resistance of pathogenic bacteria. Nonetheless, the study of antibiotic resistance at the genotype level is crucial to get information on the potential of those bacteria to develop and disseminate resistance against antibiotics (Palmer and Kishony, 2013). Erythromycin, tetracyclines, gentamicin, and vancomycin are the most used antibiotics for the treatment of staphylococcal infections, but resistance genes against these antibiotics have been described in staphylococcal clinical isolates (Duran et al., 2012; Emaneini et al., 2013). Therefore, we searched in our 25 clinical isolates for the presence of genes involved in the resistance to these antibiotics.

Macrolide antibiotics, such as erythromycin, are broadspectrum antibiotics; relevantly, anti-biofilm activities have been assigned to them (Parra-Ruiz et al., 2012; Zhao et al., 2015). In this work, $60 \%$ of the isolates were phenotypically resistant to erythromycin. At the genotype level, different studies have reported the prevalence of the ermC gene in staphylococci (Duran et al., 2012; Schiwon et al., 2013); in our study, the erm $C$ gene was identified in all the clinical isolates. Although a low prevalence of the ermB gene has been described in Staphylococcus (Zmantar et al., 2011), in our study, 72\% of the isolates harbored the ermB gene.

After penicillin, tetracyclines are the second most widely used group of antibiotics worldwide (van Hoek et al., 2011). Resistance to tetracycline can be encoded in plasmid-located tet genes such as tet $K$ and tet $L$, or, alternatively, in genes located in the chromosome or transposons such as tetM and tetO (Emaneini et al., 2013). A high incidence of the tetK gene (92\%) was observed here, whereas only one isolate contained the tet $M$ gene. Several studies have reported the coexistence of both tet $M$ and $t e t K$ genes in staphylococci strains (Duran et al., 2012; Camoez et al., 2013; Emaneini et al., 2013; Schiwon et al., 2013). Here, a disagreement between phenotypic and genotypic data was observed, since only $8 \%$ of the isolates were phenotypically resistant to tetracycline.

Aminoglycosides, such as gentamicin, are broad-spectrum antibiotics used against $S$. aureus infections. Aminoglycoside modifying enzymes (AME) are used by bacteria to abolish the effect of these antibiotics. In $S$. aureus strains, one of the most common genes encoding AME is the aac6-aph $2 a$ gene (Emaneini et al., 2013). In our study, $88 \%$ of the isolates contained this gene, in agreement with other studies on staphylococcal isolates (Duran et al., 2012; Emaneini et al., 2013). In terms of the phenotype, $44 \%$ of the isolates showed resistance to gentamicin (Table 1). Similar discrepancies between phenotypic and genotypic results have been observed by other authors (Duran et al., 2012; Emaneini et al., 2013).

The lack of correlation between resistance phenotypic and genotypic data could be due to mutations in genes resulting in non-functional proteins, as well as to the lack of gene expression (Martineau et al., 2000). Also, methods to detect antibiotic resistance phenotype are influenced by technical variables such as temperature, incubation time, inoculum density and so on (Baddour et al., 2007). Likewise, the pattern of negative resistance phenotype together with a positive resistance genotype can be due to the presence of pseudogenes (Davis et al., 2011). As a consequence, it is essential to take this fact into account because it indicates that bacteria have the potential to be resistant to more antibiotics than those shown phenotypically. 
Vancomycin has been used to treat staphylococcal infections, mainly methicillin resistant $S$. aureus (Huebner and Goldmann, 1999). In the late 1980s, the emergence of vancomycin resistance was reported for the first time (van Hoek et al., 2011). One of the genes responsible for vancomycin resistance is the $v a n B$ gene (van Hoek et al., 2011), which was only found in isolate 10. This low incidence of the $v a n B$ gene, together with the fact that all isolates were phenotypically sensitive to vancomycin (Table 1), suggest that (i) vancomycin is still one of the best options for the treatment of staphylococcal infections and (ii) it should be then used judiciously.

Concerning the presence of horizontal transfer genes, plasmid pSK41 is a prototypical multiresistance plasmid of $46 \mathrm{~kb}$ from $S$. aureus (Berg et al., 1998). Therefore, we searched for pre pSK41 $_{1}$ and nes $s_{\mathrm{pSK} 41}$ genes, as well as for five different tra genes involved in the conjugative transfer of plasmid pSK41, in our clinical isolates. Although all the isolates, except for one, contained the pre $_{\mathrm{pSK} 41}$ gene, only $32 \%$ of the isolates harbored the nes $\mathrm{pSK} 41$ gene. In addition, $20 \%$ of the isolates contained the five tra genes tested here. According to these results, and taking into account that isolates 11 and 17 harbored plasmids of around $46 \mathrm{~kb}$, we speculate that these strains could contain pSK41-type plasmids. Other studies have identified plasmids of the pSK41 family in geographically diverse isolates of both $S$. aureus and CoNS (Berg et al., 1998). The coexistence of pre $e_{\mathrm{pSK} 41}$ and nes $\mathrm{pSK}_{11}$ genes, together with tra genes, in some of our isolates, points to a risk of dissemination of resistance traits.

pT181 plasmid is also common among staphylococci (Khan and Novick, 1983; Novick, 1989). Then, we tested for the presence of the relaxase pre $_{\mathrm{pT} 181}$ gene responsible for pT181 mobilization. All isolates harbored the pre $_{\mathrm{pT} 181}$ relaxase gene, suggesting that pT181-type plasmids could be present in all of the samples. pT181 is a low copy number plasmid and then, not surprisingly, we could not detect it in the electrophoretic gels; however, it may be present at undetectable amounts in some strains. This is of great concern especially in those strains where potentially conjugative plasmids that could mobilize these small plasmids are present.

Finally, in general, S. epidermidis isolates have shown a higher biofilm-forming capacity than $S$. aureus isolates Although, the 25 isolates studied here were obtained from biofilms present in the clinical environment, some of the $S$. aureus isolates were unable to form biofilms under our experimental conditions. This is probably because biofilms in clinical conditions take longer times to form, in comparison to the standardized in vitro method used here, in which $24 \mathrm{~h}$ was the biofilm-forming time.

The fact that our clinical isolates contained both antibiotic resistance and horizontal transfer genes, as well as conjugative and/or mobilizable plasmids, suggest the possibility of their disseminating antibiotic resistance to other bacteria. Here, it must be stated that, due to the abovementioned presence of chromosomal DNA in our extracted DNA samples, we cannot rule out the possibility that the antibiotic resistance genes identified here were encoded in the chromosomal DNA. However, as reflected in Figures 1, 2, the majority of the extracted DNA corresponds to plasmid DNA. For example, the high incidence of the plasmid-encoded tet $K$ gene in our isolates could support this fact. In any case, genes encoded in the chromosome can also be mobilized between bacterial cells. For instance, transposons can mobilize chromosomal genes by jumping into plasmids or phages which can then be transferred into other cells (Frost et al., 2014). On the other hand, the conjugation process can also occur via chromosomally integrated conjugative elements, such as conjugative transposons. Integrated conjugative elements are known to encode proteins that facilitate their own transfer and sometimes the transfer of other cellular DNA from the donor (Frost et al., 2014). Indeed, as reported by Wilkins and Frost (2001), many plasmids and integrated conjugative elements can effect the transfer of chromosomal DNA. Then, if some of the antibiotic resistance genes identified here were encoded in the chromosomal DNA present in some of our samples, the risk of transfer to other bacterial cells would still exist, although a priori lower than if they were encoded in the observed plasmids.

Recent studies underline the importance of collecting more epidemiological data on antibiotic resistance, in order to design novel control strategies for this growing global health problem (Frieri et al., 2016). The isolation and molecular characterization of plasmids from nosocomial pathogens will provide valuable information in the search for new strategies to control the dissemination of antibiotic resistance among clinical pathogens.

\section{AUTHOR CONTRIBUTIONS}

SÁ and IÁR: Acquisition of the data, writing and revision of the content, approval of the last version of the work. OG: Revision of the content, approval of the last version of the work. CG: Writing and revision of the content, approval of the last version and ensuring accuracy and integrity of the work. EG: Design of the work, revision of the content, approval of the last version, and ensuring accuracy and integrity of the work. IA: Design of the work and the acquisition of the data, writing, and revision of the content, approval of the last version and ensuring accuracy and integrity of the work.

\section{ACKNOWLEDGMENTS}

This work was financially supported by the Spanish Ministry of Economy (Grant No BFU2012-36241) and MICINN (Grant No. BFU2010-22103). SÁ and OG were graduate students supported by the Basque Government and Fundación Biofísica Bizkaia. At the moment, IÁR is a graduate student supported by the Basque Government. We thank Eneritz Bilbao for excellent technical assistance. We thank Prof. Pérez-Trallero and Dr. Alonso from the Hospital Universitario Donostia for providing the clinical isolates, and Prof. Quindós and Aketza Varona from the University of the Basque Country, and Dr. Rodríguez-Lázaro and Dr. Hernández from the Instituto Tecnológico Agrario de Castilla y León, Spain for assistance with the PFGE.

\section{SUPPLEMENTARY MATERIAL}

The Supplementary Material for this article can be found online at: https://www.frontiersin.org/articles/10.3389/fmicb. 2017.02018/full\#supplementary-material 


\section{REFERENCES}

Baddour, M. M., AbuElKheir, M. M., and Fatani, A. J. (2007). Comparison of mecA polymerase chain reaction with phenotypic methods for the detection of methicillin-resistant Staphylococcus aureus. Curr. Microbiol. 55, 473-479. doi: 10.1007/s00284-007-9015-6

Barton, B. M., Harding, G. P., and Zuccarelli, A. J. (1995). A general method for detecting and sizing large plasmids. Anal. Biochem. 226, 235-240. doi: 10.1006/abio.1995.1220

Berg, T., Firth, N., Apisiridej, S., Hettiaratchi, A., Leelaporn, A., and Skurray, R. A. (1998). Complete nucleotide sequence of pSK41: evolution of staphylococcal conjugative multiresistance plasmids. J. Bacteriol. 180, 4350-4359.

Böckelmann, U., Dorries, H., Ayuso-Gabella, M. N., de Salgot Marcay, M., Tandoi, V., Levantesi, C., et al. (2009). Quantitative PCR monitoring of antibiotic resistance genes and bacterial pathogens in three European artificial groundwater recharge systems. Appl. Environ. Microbiol. 75, 154-163. doi: 10.1128/AEM.01649-08

Broszat, M., Nacke, H., Blasi, R., Siebe, C., Huebner, J., Daniel, R., et al. (2014). Wastewater irrigation increases the abundance of potentially harmful gammaproteobacteria in soil in Mezquital Valley, Mexico. Appl. Environ. Microbiol. 80, 5282-5291. doi: 10.1128/AEM.01295-14

Camoez, M., Sierra, J. M., Pujol, M., Hornero, A., Martin, R., and Domínguez, M. A. (2013). Prevalence and molecular characterization of methicillin-resistant Staphylococcus aureus ST398 resistant to tetracycline at a Spanish Hospital over 12 years. PLoS ONE 8:e72828. doi: 10.1371/journal.pone.0072828

Christensen, B. B., Sternberg, C., Andersen, J. B., Eberl, L., Moller, S., Givskov, M., et al. (1998). Establishment of new genetic traits in a microbial biofilm community. Appl. Environ. Microbiol. 64, 2247-2255.

Christensen, G. D., Simpson, W. A., Younger, J. J., Baddour, L. M., Barrett, F. F., Melton, D. M., et al. (1985). Adherence of coagulase-negative staphylococci to plastic tissue culture plates: a quantitative model for the adherence of staphylococci to medical devices. J. Clin. Microbiol. 22, 996-1006

Costerton, J. W., Stewart, P. S., and Greenberg, E. P. (1999). Bacterial biofilms: a common cause of persistent infections. Science 284, 1318-1322. doi: $10.1126 /$ science. 284.5418 .1318

D'Alvise, P. W., Sjoholm, O. R., Yankelevich, T., Jin, Y., Wuertz, S., and Smets, B. F. (2010). TOL plasmid carriage enhances biofilm formation and increases extracellular DNA content in Pseudomonas putida KT2440. FEMS Microbiol. Lett. 312, 84-92. doi: 10.1111/j.1574-6968.2010.02105.x

Davis, M. A., Besser, T. E., Orfe, L. H., Baker, K. N., Lanier, A. S., Broschat, S. L., et al. (2011). Genotypic-phenotypic discrepancies between antibiotic resistance characteristics of Escherichia coli isolates from calves in management settings with high and low antibiotic use. Appl. Environ. Microbiol. 77, 3293-3299. doi: 10.1128/AEM.02588-10

Di Rosa, R., Creti, R., Venditti, W., D’Amelio, R., Arciola, C. R., Montanaro, L., et al. (2006). Relationship between biofilm formation, the enterococcal surface protein and gelatinase in clinical isolates of Enterococcus faecalis and Enterococcus faecium. FEMS Micobiol. Lett. 256, 145-150. doi: 10.1111/j.1574-6968.2006.00112.x

Duran, N., Ozer, B., Duran, G. G., Onlen, Y., and Demir, C. (2012). Antibiotic resistance genes and susceptibility patterns in staphylococci. Indian J. Med. Res. 135, 389-396.

Emaneini, M., Bigverdi, R., Kalantar, D., Soroush, S., Jabalameli, F., Noorazar Khoshgnab, B., et al. (2013). Distribution of genes encoding tetracycline resistance and aminoglycoside modifying enzymes in Staphylococcus aureus strains isolated from a burn center. Ann. Burns Fire Disasters 26, 76-80.

Firth, N., Ridgway, K. P., Byrne, M. E., Fink, P. D., Johnson, L., Paulsen, I. T., et al. (1993). Analysis of a transfer region from the staphylococcal conjugative plasmid pSK41. Gene 136, 13-25. doi: 10.1016/0378-1119(93)90442-6

Frieri, M., Kumar, K., and Boutin, A. (2016). Antibiotic resistance. J. Infect. Public Health 10, 369-378. doi: 10.1016/j.jiph.2016.08.007

Frost, L. S., Leplae, R., Summers, A. O., and Toussaint, A. (2014). Mobile genetic elements: the agents of open source evolution. Nat. Rev. Microbiol. 3, 722-732. doi: $10.1038 /$ nrmicro 1235

Germond, J. E., Vogt, V. M., and Hirt, B. (1974). Characterization of the singlestrand-specific nuclease S1 activity on double-stranded supercoiled polyoma DNA. Eur. J. Biochem. 43, 591-600. doi: 10.1111/j.1432-1033.1974.tb03 446.x
Ghigo, J. M. (2001). Natural conjugative plasmids induce bacterial biofilm development. Nature 412, 442-445. doi: 10.1038/35086581

Gryczan, T., Israeli-Reches, M., Del Bue, M., and Dubnau, D. (1984). DNA sequence and regulation of ermD, a macrolide-lincosamidestreptogramin $\mathrm{B}$ resistance element from Bacillus licheniformis. Mol. Gen. Genet. 194, 349-356. doi: 10.1007/BF00425543

Guridi, A., Diederich, A. K., Aguila-Arcos, S., Garcia-Moreno, M., Blasi, R., Broszat, M., et al. (2015). New antimicrobial contact catalyst killing antibiotic resistant clinical and waterborne pathogens. Mater. Sci. Eng. C Mater. Biol. Appl. 50, 1-11. doi: 10.1016/j.msec.2015.01.080

Hausner, M., and Wuertz, S. (1999). High rates of conjugation in bacterial biofilms as determined by quantitative in situ analysis. Appl. Environ. Microbiol. 65, $3710-3713$

Hoiby, N., Bjarnsholt, T., Givskov, M., Molin, S., and Ciofu, O. (2010). Antibiotic resistance of bacterial biofilms. Int. J. Antimicrob. Agents 35, 322-332. doi: 10.1016/j.ijantimicag.2009.12.011

Huebner, J., and Goldmann, D. A. (1999). Coagulase-negative staphylococci: role as pathogens. Annu. Rev. Med. 50, 223-236. doi: 10.1146/annurev.med.50.1.223

Khan, S. A., and Novick, R. P. (1983). Complete nucleotide sequence of pT181, a tetracycline resistance plasmid from Staphylococcus aureus. Plasmid 10, 251-259. doi: 10.1016/0147-619X(83)90039-2

Khan, S. A., Carleton, S. M., and Novick, R. P. (1981). Replication of plasmid pT181 DNA in vitro: requirement for a plasmid-encoded product. Proc. Natl. Acad. Sci. U.S.A. 78, 4902-4906. doi: 10.1073/pnas.78.8.4902

Kloos, W. E., and Bannerman, T. L. (1994). Update on clinical significance of coagulase-negative staphylococci. Clin. Microbiol. Rev. 7, 117-140. doi: 10.1128/CMR.7.1.117

Le, K. Y., Dastgheyb, S., Ho, T. V., and Otto, M. (2014). Molecular determinants of staphylococcal biofilm dispersal and structuring. Front. Cell. Infect. Microbiol. 4:167. doi: $10.3389 /$ fcimb. 2014.00167

Mack, D., Becker, P., Chatterjee, I., Dobinsky, S., Knobloch, J. K., Peters, G., et al. (2004). Mechanisms of biofilm formation in Staphylococcus epidermidis and Staphylococcus aureus: functional molecules, regulatory circuits, and adaptive responses. Int. J. Med. Microbiol. 294, 203-212. doi: 10.1016/j.ijmm.2004.06.015

Martineau, F., Picard, F. J., Lansac, N., Menard, C., Roy, P. H., Ouellette, M., et al. (2000). Correlation between the resistance genotype determined by multiplex PCR assays and the antibiotic susceptibility patterns of Staphylococcus aureus and Staphylococcus epidermidis. Antimicrob. Agents Chemother.. 44, 231-238. doi: 10.1128/AAC.44.2.231-238.2000

Miele, A., Bandera, M., and Goldstein, B. P. (1995). Use of primers selective for vancomycin resistance genes to determine van genotype in enterococci and to study gene organization in VanA isolates. Antimicrob. Agents Chemother. 39, 1772-1778. doi: 10.1128/AAC.39.8.1772

Molin, S., and Tolker-Nielsen, T. (2003). Gene transfer occurs with enhanced efficiency in biofilms and induces enhanced stabilisation of the biofilm structure. Curr. Opin. Biotechnol. 14, 255-261. doi: 10.1016/S0958-1669(03)00036-3

Monod, M., Mohan, S., and Dubnau, D. (1987). Cloning and analysis of ermG, a new macrolide-lincosamide-streptogramin B resistance element from Bacillus sphaericus. J. Bacteriol. 169, 340-350. doi: 10.1128/jb.169.1.340-350.1987

Novick, R. P. (1989). Staphylococcal plasmids and their replication. Annu. Rev. Microbiol. 43, 537-565. doi: 10.1146/annurev.mi.43.100189.002541

Otto, M. (2008). Staphylococcal biofilms. Curr. Top. Microbiol. Immunol. 322, 207-228. doi: 10.1007/978-3-540-75418-3_10

Otto, M. (2012). Molecular basis of Staphylococcus epidermidis infections. Semin. Immunopathol. 34, 201-214. doi: 10.1007/s00281-011-0296-2

Palmer, A. C., and Kishony, R. (2013). Understanding, predicting and manipulating the genotypic evolution of antibiotic resistance. Nat. Rev. Genet. 14, 243-248. doi: 10.1038/nrg3351

Parra-Ruiz, J., Vidaillac, C., and Rybak, M. J. (2012). Macrolides and staphylococcal biofilms. Rev. Esp. Quimioter. 25, 10-16.

Paulsen, I. T., Banerjei, L., Myers, G. S., Nelson, K. E., Seshadri, R., Read, T. D., et al. (2003). Role of mobile DNA in the evolution of vancomycin resistant Enterococcus faecalis. Science 299, 2071-2074. doi: 10.1126/science.1080613

Perreten, V., Vorlet-Fawer, L., Slickers, P., Ehricht, R., Kuhnert, P., and Frey, J. (2005). Microarray-based detection of 90 antibiotic resistance genes of gram-positive bacteria. J. Clin. Microbiol. 43, 2291-2302. doi: 10.1128/JCM.43.5.2291-2302.2005 
Pfaller, M. A., and Herwaldt, L. A. (1988). Laboratory, clinical and epidemiological aspects of coagulase-negative staphylococci. Clin. Microbiol. Rev. 1, 281-299. doi: 10.1128/CMR.1.3.281

Reisner, A., Höller, B. M., Molin, S., and Zechner, E. L. (2006). Synergistic effects in mixed Escherichia coli biofilms: conjugative plasmid transfer drives biofilm expansion. J. Bacteriol. 188, 3582-3588. doi: 10.1128/JB.188.10.3582-358 8.2006

Sambrook, J., and Russel, D. W. (2001). Molecular Cloning. A Laboratory Manual. New York, NY: Cold Spring Harbor Laboratory Press.

Schiwon, K., Arends, K., Rogowski, K. M., Fürch, S., Prescha, K., Sakinc, T., et al. (2013). Comparison of antibiotic resistance, biofilm formation and conjugative transfer of Staphylococcus and Enterococcus isolates from International Space Station and Antarctic Research Station Concordia. Microb. Ecol. 65, 638-651. doi: 10.1007/s00248-013-0193-4

Schwarz, F. V., Perreten, V., and Teuber, M. (2001). Sequence of the 50-kb conjugative multiresistance plasmid pRE25 from Enterococcus faecalis RE25. Plasmid 46, 170-187. doi: 10.1006/plas.2001.1544

Shearer, J. E., Wireman, J., Hostetler, J., Forberger, H., Borman, J., Gill, J., et al. (2011). Major families of multiresistant plasmids from geographically and epidemiologically diverse staphylococci. G3 1, 581-591. doi: $10.1534 / \mathrm{g} 3.111 .000760$

Smillie, C., Garcillán-Barcia, M. P., Francia, M. V., Rocha, E. P., and de la Cruz, F. (2010). Mobility of plasmids. Microbiol. Mol. Biol. Rev. 74, 3434-3452. doi: 10.1128/MMBR.00020-10

Stewart, P. S., and Costerton, J. W. (2001). Antibiotic resistance of bacteria in biofilms. Lancet 358, 135-138. doi: 10.1016/S0140-6736(01)05321-1

Tenover, F. C., and Rasheed, J. K. (2004). "Detection of antimicrobial resistance genes and mutations associated with antimicrobial resistance in microorganisms," in Molecular Microbiology: Diagnostics Principles and Practice, Vol. 1, eds D. H. Persing, F. G. Tenover, J. Versalovic, T. Yuer, W. T. J, Relman (Washington, DC: ASM Press), 391-406.

Tong, S. Y., Chen, L. F., and Fowler, V. G. Jr. (2012). Colonization, pathogenicity, host susceptibility, and therapeutics for Staphylococcus aureus: what is the clinical relevance? Semin. Immunopathol. 34, 185-200. doi: 10.1007/s00281-011-0300-x

van Hoek, A. H., Mevius, D., Guerra, B., Mullany, P., Roberts, A. P., and Aarts, H. J. (2011). Acquired antibiotic resistance: an overview. Front. Microbiol. 2:203. doi: 10.3389/fmicb.2011.00203

Wilkins, B. M., and Frost, L. S. (2001). "Mechanisms of gene exchange between bacteria," in Molecular Medical Microbiology, ed M. Sussman (London: Academic Press), 355-400.

Yang, X., Ma, Q., and Wood, T. K. (2008). The R1 conjugative plasmid increases Escherichia coli biofilm formation through an envelope stress response. Appl. Environ. Microbiol. 74, 2690-2699. doi: 10.1128/AEM.02809-07

Zhao, Y. L., Zhou, Y. H., Chen, J. Q., Huang, Q. Y., Han, Q., Liu, B., et al. (2015). Quantitative proteomic analysis of sub-MIC erythromycin inhibiting biofilm formation of S. suis in vitro. J. Proteomics 116, 1-14. doi: 10.1016/j.jprot.2014.12.019

Zmantar, T., Kouidhi, B., Miladi, H., and Bakhrouf, A. (2011). Detection of macrolide and disinfectant resistance genes in clinical Staphylococcus aureus and coagulase-negative staphylococci. BMC Res. Notes 4:453. doi: 10.1186/1756-0500-4-453

Conflict of Interest Statement: The authors declare that the research was conducted in the absence of any commercial or financial relationships that could be construed as a potential conflict of interest.

The reviewer GDS and handling Editor declared their shared affiliation.

Copyright (C) 2017 Águila-Arcos, Álvarez-Rodríguez, Garaiyurrebaso, Garbisu, Grohmann and Alkorta. This is an open-access article distributed under the terms of the Creative Commons Attribution License (CC BY). The use, distribution or reproduction in other forums is permitted, provided the original author(s) or licensor are credited and that the original publication in this journal is cited, in accordance with accepted academic practice. No use, distribution or reproduction is permitted which does not comply with these terms. 